\title{
Amycolatopsis salitolerans sp. nov., a filamentous actinomycete isolated from a hypersaline habitat
}

\author{
Correspondence \\ Tong-Wei Guan \\ guantongwei78@126.com \\ Li-Li Zhang \\ zhang63lyly@yahoo.com.cn
}

\author{
Tong-Wei Guan, ${ }^{1,2,3}$ Zhan-Feng Xia, ${ }^{1}$ Shu-Kun Tang, ${ }^{2}$ Nan Wu ${ }^{4}$ \\ Zheng-Jun Chen, ${ }^{1}$ Ying Huang, ${ }^{3}$ Ji-Sheng Ruan, ${ }^{3}$ Wen-Jun $\mathrm{Li}^{2}$ \\ and Li-Li Zhang ${ }^{1}$
}
${ }^{1}$ Key Laboratory of Protection and Utilization of Biological Resources in Tarim Basin of Xinjiang Production and Construction Corps, Tarim University, Alar, Xinjiang 843300, PR China
${ }^{2}$ Key Laboratory for Microbial Resources of the Ministry of Education, Laboratory for Conservation and Utilization of Bio-resources, Yunnan Institute of Microbiology, Yunnan University, Kunming, Yunnan 650091, PR China
${ }^{3}$ State Key Laboratory of Microbial Resources, Institute of Microbiology, Chinese Academy of Sciences, Beijing 100101, PR China
${ }^{4}$ Key Laboratory of Biogeography and Bioresource in Arid Land, Xinjiang Institute of Ecology and Geography, Chinese Academy of Sciences, Urumqi 830011, PR China

\begin{abstract}
A novel actinomycete strain, designated TRM $\mathrm{F}_{103}{ }^{\top}$, was isolated from a hypersaline habitat of the Tarim basin in Xinjiang province, north-west China. Phylogenetic analysis based on 16S rRNA gene sequences showed that the isolate belonged to the genus Amycolatopsis and was most closely related to Amycolatopsis halophila YIM 93223 ${ }^{\top}$ (99.3\% 16S rRNA gene sequence similarity). However, DNA-DNA relatedness between these two strains, based on triplicate experiments, was only $31.6 \%$. The isolate contained meso-diaminopimelic acid and ribose, glucose and galactose as the major whole-cell sugars. The predominant menaquinone was MK$8\left(\mathrm{H}_{4}\right)$. The major fatty acids were iso- $\mathrm{C}_{16: 0}$ and $\mathrm{C}_{16: 0}$. The polar lipids were diphosphatidylglycerol, phosphatidylmethylethanolamine, phosphatidylethanolamine and glucosamine-containing phospholipids. The $\mathrm{G}+\mathrm{C}$ content of the genomic DNA was $66.4 \mathrm{~mol} \%$. The phenotypic data clearly distinguished the isolate from its closest relatives. The combined phylogenetic, chemotaxonomic and phenotypic data indicate that the isolate represents a novel species of the genus Amycolatopsis. The proposed name is Amycolatopsis salitolerans sp. nov.,

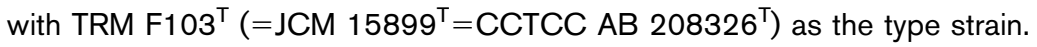

The genus Amycolatopsis (Lechevalier et al., 1986), first proposed as a novel genus of nocardioform actinomycetes in 1986, was classified in the family Pseudonocardiaceae, suborder Pseudonocardineae (Stackebrandt et al., 1997) on the basis of $16 \mathrm{~S}$ rRNA gene sequence analysis. Not long ago, we described a halophilic species in the genus Amycolatopsis, namely Amycolatopsis halophila (Tang et al., 2010), which was isolated from a salt lake in Xinjiang province, north-west China. Recently, during a study of the cultivable aerobic bacterial community in a hypersaline habitat, a novel halotolerant, filamentous, Amycolatopsis-like actinomycete was isolated from a similar hypersaline environment in the Tarim basin, Xinjiang province; the habitat and

The GenBank/EMBL/DDBJ accession number for the $16 \mathrm{~S}$ rRNA gene sequence of strain TRM F103 ${ }^{\top}$ is $\mathrm{HQ} 436534$.

A supplementary figure is available with the online version of this paper. precise location were described previously (Guan et al., 2010).

Strain TRM F103 ${ }^{\mathrm{T}}$ was isolated under aerobic conditions on GTY agar (containing $1^{-1}: 5 \mathrm{~g}$ glucose, $0.5 \mathrm{~g}$ tryptone, 2 g yeast extract, $1 \mathrm{~g} \mathrm{CaCO}_{3}, 0.5 \mathrm{~g} \mathrm{~K}_{2} \mathrm{PO}_{4}$ and $16.0 \mathrm{~g}$ agar; $\mathrm{pH} 7.0-7.5)$ supplemented with $10 \%(\mathrm{w} / \mathrm{v}) \mathrm{NaCl}$. The strain was purified and maintained on GTY agar slants supplemented with $5 \% \mathrm{NaCl}$ and stored as a suspension in $20 \%(\mathrm{v} / \mathrm{v})$ glycerol at $-20{ }^{\circ} \mathrm{C}$ or as lyophilized cells. Biomass for chemical and molecular studies was obtained by cultivation in shake flasks (about 170 r.p.m.) using GTY broth supplemented with $5 \% \mathrm{NaCl}\left(\mathrm{pH} \mathrm{7.0)}\right.$ at $37{ }^{\circ} \mathrm{C}$ for 1 week. A. halophila YIM $93223^{\mathrm{T}}$ was also analysed in this study to compare phenotypic characteristics and to determine DNA-DNA relatedness.

Amplification and sequencing of the 16S rRNA gene was performed as described by Cui et al. (2001) using a 


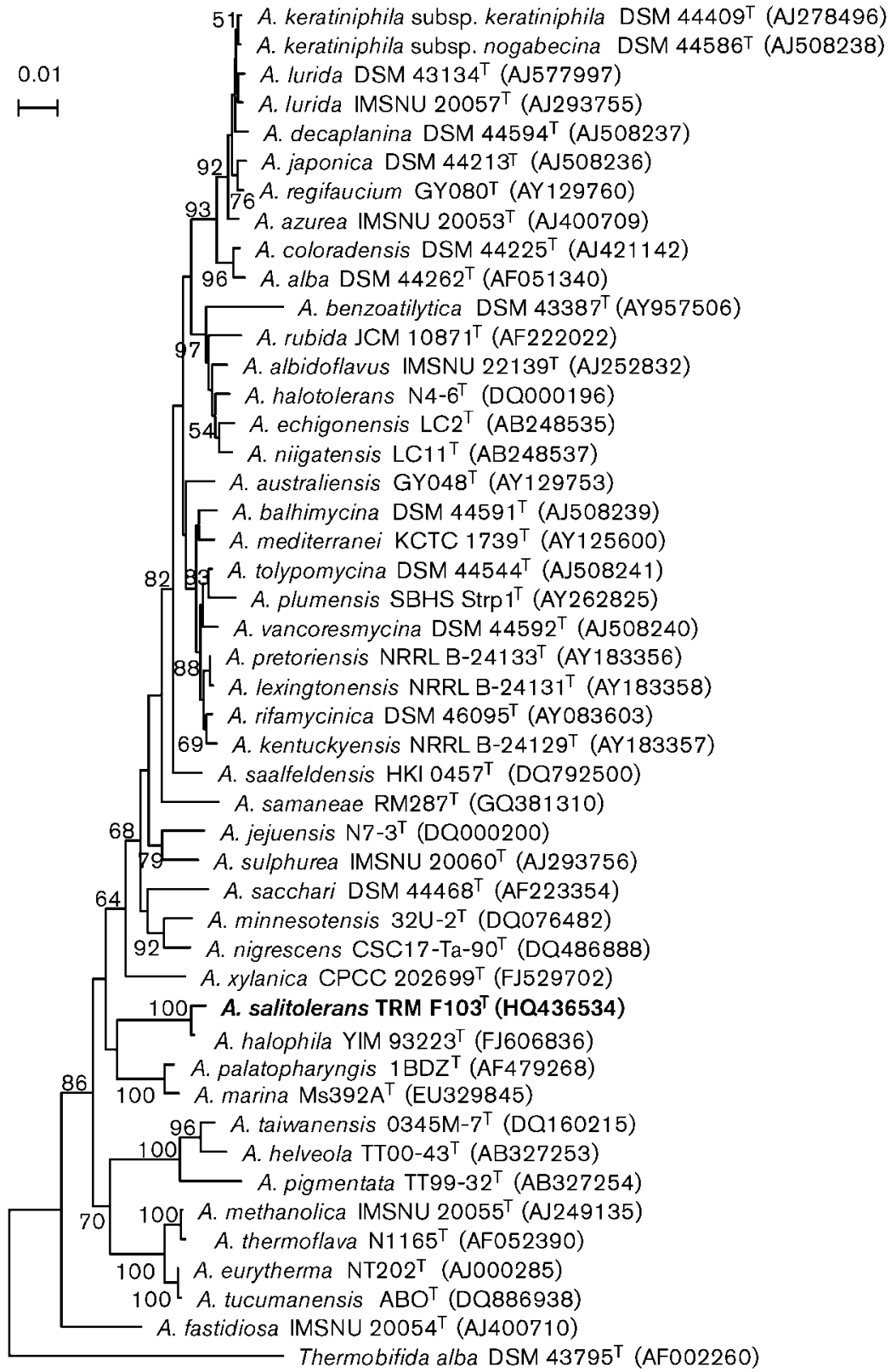

Fig. 1. Neighbour-joining tree based on $16 \mathrm{~S}$ rRNA gene sequences showing the phylogenetic relationships of strain TRM $\mathrm{F}_{10}{ }^{\mathrm{T}}$ with members of the genus Amycolatopsis. Bootstrap values $(>50 \%)$ based on 1000 replicates are shown at branch nodes. Bar, 0.01 substitutions per nucleotide position.
PCR-product purification kit (Sangon). An almost-complete (1418 nt) 16S rRNA gene sequence of strain TRM $\mathrm{F} 103^{\mathrm{T}}$ was obtained. Multiple alignments and sequence similarity calculations with sequences of the closest neighbours were carried out using the EzTaxon server 2.0 (Chun et al., 2007). Phylogenetic analysis was performed on a manual alignment with sequences of type strains of all recognized species in the genus Amycolatopsis using MEGA version 4.0 (Tamura et al., 2007). Phylogenetic trees were constructed using the neighbour-joining (Saitou \& Nei, 1987) and maximum-parsimony (Fitch, 1971) methods. Evolutionary distance matrices were generated as described by Kimura (1980). Topology of the phylogenetic tree was evaluated by the bootstrap resampling method of Felsenstein (1985) with 1000 replications.
It was evident from 16S rRNA gene sequence analysis that strain TRM F103 ${ }^{\mathrm{T}}$ belonged to the genus Amycolatopsis. Strain TRM F $103^{\mathrm{T}}$ formed a monophyletic clade that was associated with A. halophila YIM $93223^{\mathrm{T}}$, which was supported by bootstrap values of $100 \%$ in the neighbour-joining analysis (Fig. 1) and $99 \%$ in the maximum-parsimony analysis (data not shown). Strain TRM F103 ${ }^{\mathrm{T}}$ exhibited highest sequence similarity with A. halophila YIM $93223^{\mathrm{T}}$ (99.3\% 16S rRNA gene sequence similarity). Other members of the genus displayed $<96.0 \% 16 \mathrm{~S}$ rRNA gene sequence similarity with the isolate. DNA-DNA hybridization was performed using the method described by $\mathrm{He}$ et al. (2005). Strain TRM F103 ${ }^{\mathrm{T}}$ and A. halophila YIM $93223^{\mathrm{T}}$ showed $31.6 \%$ DNA-DNA relatedness (based on triplicate experiments). Considering $70 \%$ DNA-DNA relatedness as 
the cut-off point for species delineation (Wayne et al., 1987), strain TRM F103 ${ }^{\mathrm{T}}$ represents a novel species of the genus Amycolatopsis.

Mycelial morphological characteristics were examined by light microscopy (BH-2; Olympus) and scanning electron microscopy (JSM 5600LV; JEOL) of 13-day-old cultures grown on GTY agar supplemented with $5 \% \mathrm{NaCl}$. The Gram-reaction was performed as described by Gerhardt et al. (1994). Cultural characteristics were determined after incubation for 2-3 weeks by methods used by the International Streptomyces Project (ISP) (Shirling \& Gottlieb, 1966). All media were supplemented with $5 \%(\mathrm{w} / \mathrm{v}) \mathrm{NaCl}$ for growth. The colours of substrate and aerial mycelia and any soluble pigments produced were determined by comparison with chips from the ISCC-NBS colour charts (Kelly, 1964). Unless specified otherwise, physiological properties were examined using ISP 4 as the basal medium. Growth was tested at $4,10,20,30,37,42,45$, and $50{ }^{\circ} \mathrm{C}$ and $\mathrm{pH} 4.0-12.0$ (at intervals of one $\mathrm{pH}$ unit), with the $\mathrm{pH}$ of media adjusted after autoclaving with $1 \mathrm{M} \mathrm{HCl}$ and $1 \mathrm{M}$ $\mathrm{NaOH}$. Growth with $0-20 \%(\mathrm{w} / \mathrm{v}) \mathrm{NaCl}$ (at intervals of $1 \%$ ) was tested on ISP 4 . Standard physiological tests were carried out according to the methods described by Smibert \& Krieg (1994). Enzyme activities were studied using the API ZYM substrate panels (bioMérieux). Susceptibility to antibiotics was tested by the method of Williams (1967).
Strain TRM F103 ${ }^{\mathrm{T}}$ grew well on inorganic salts-starch agar, Czapek's agar, oatmeal agar and potato agar and grew weakly on glycerol-asparagine agar and yeast extract-malt extract agar, but did not grow on nutrient agar. The aerial mycelium was white and the substrate mycelium was white-yellow. No soluble pigments were produced. Other phenotypic characteristics are given in Table 1 and the species description.

The isomer type of diaminopimelic acid in the cell-wall peptidoglycan was determined by the method of Hasegawa et al. (1983). Whole-cell sugars were analysed as described by Staneck \& Roberts (1974). Menaquinones were extracted using the method of Collins et al. (1977) and analysed by HPLC (Groth et al., 1997). Polar lipids were extracted, examined by two-dimensional TLC and identified using the procedures of Minnikin et al. (1984). Cellular fatty acid composition was determined as described by Sasser (1990) using the Microbial Identification System (MIDI). Mycolic acids were checked by the acid methanolysis method of Minnikin et al. (1980). The G+C content of the DNA was determined using HPLC (Mesbah et al., 1989). The G+C content of genomic DNA was $66.4 \mathrm{~mol} \%$, which is comparable with that of $A$. halophila YIM $93223^{\mathrm{T}}(66.1 \mathrm{~mol} \%)$ (Tang et al., 2010). According to the chemotaxonomic analysis, strain TRM F $103^{\mathrm{T}}$ was clearly distinguishable from its closest phylogenetic neighbours. For example, the polar

Table 1. Differential characteristics of strain TRM $F 103^{\top}$ and its closest phylogenetic neighbours

Strains: 1, Amycolatopsis salitolerans sp. nov. TRM F103 ${ }^{\mathrm{T}}$; 2, A. halophila YIM 93223 ${ }^{\mathrm{T}}$ (Tang et al., 2010); 3, A. marina Ms392A ${ }^{\mathrm{T}}$ (Bian et al., 2009); 4, A. palatopharyngis $1 \mathrm{BDZ}^{\mathrm{T}}$ (Huang et al., 2004). +, Positive; w, weakly positive; -, negative.

\begin{tabular}{|c|c|c|c|c|}
\hline Characteristic & 1 & 2 & 3 & 4 \\
\hline $\mathrm{pH}$ range & $5.0-8.0$ & $6.0-8.0$ & $6.0-9.0$ & $6.0-10.0$ \\
\hline Catalase & + & - & + & - \\
\hline Nitrate reduction & + & - & - & + \\
\hline \multicolumn{5}{|l|}{ Decomposition of: } \\
\hline Urea & - & - & - & $\mathrm{w}$ \\
\hline \multicolumn{5}{|l|}{ Utilization of: } \\
\hline L-Arabinose & - & - & - & $\mathrm{W}$ \\
\hline L-Rhamnose & + & + & + & - \\
\hline Maltose & - & - & + & - \\
\hline $\mathrm{C}_{16: 1} \omega 7 c$ and/or iso- $\mathrm{C}_{15: 0} 2-\mathrm{OH}$ & - & 12.3 & - & - \\
\hline iso- $\mathrm{C}_{16: 0} 2-\mathrm{OH}$ & - & - & 11.4 & - \\
\hline anteiso- $\mathrm{C}_{17: 0}$ & - & - & - & 12.4 \\
\hline Predominant menaquinone & MK-8 $\left(\mathrm{H}_{4}\right)$ & $\mathrm{MK}-8\left(\mathrm{H}_{4}\right)$ & MK-9 $\left(\mathrm{H}_{4}\right)$ & $\mathrm{MK}-9\left(\mathrm{H}_{4}\right)$ \\
\hline Major whole-cell sugars* & Rib, Glc, Gal & Glc, Gal & Gal, GlcN & Gal, Man, Glc \\
\hline DNA G $+C$ content $(\mathrm{mol} \%)$ & 66.4 & 66.1 & 70.1 & 65.8 \\
\hline
\end{tabular}

${ }^{\star}$ Gal, Galactose; Glc, glucose; GlcN, glucosamine; Man, mannose; Rib, ribose. 
lipids of strain TRM F $103^{\mathrm{T}}$ included glucosamine-containing phospholipids and phosphatidylmethylethanolamine (Supplementary Fig. S1, available in IJSEM Online), which are not found in A. halophila YIM $93223^{\mathrm{T}}$. Also, the major fatty acids of strain TRM $\mathrm{F} 103^{\mathrm{T}}$ were iso- $\mathrm{C}_{16: 0}(44.6 \%)$ and $\mathrm{C}_{16: 0}(12.2 \%)$, but those of $A$. halophila YIM $93223^{\mathrm{T}}$ were iso- $\mathrm{C}_{16: 0}(28.9 \%), \mathrm{C}_{16: 0}(18.6 \%)$ and $\mathrm{C}_{16: 1} \omega 7 c$ and/or iso$\mathrm{C}_{15: 0} 2-\mathrm{OH}(12.3 \%)$. In addition, the predominant menaquinone of strain TRM $\mathrm{F} 103^{\mathrm{T}}$ was MK-8 $\left(\mathrm{H}_{4}\right)(88.1 \%)$, whereas that of Amycolatopsis marina and Amycolatopsis palatopharyngis, which are also closely related to the isolate, was MK-9 $\left(\mathrm{H}_{4}\right)$. Strain TRM F103 ${ }^{\mathrm{T}}$ also contained MK- $8\left(\mathrm{H}_{6}\right)$ $(6.2 \%)$, MK-9 $\left(\mathrm{H}_{4}\right)(4.7 \%)$ and MK- $8\left(\mathrm{H}_{2}\right)(1 \%)$ as minor menaquinones. Details of other chemotaxonomic characteristics are given in Table 1 and the species description.

On the basis of the phenotypic, genotypic and DNA-DNA hybridization data presented here, strain TRM $\mathrm{F} 103^{\mathrm{T}}$ is considered to represent a novel species of the genus Amycolatopsis, for which the name Amycolatopsis salitolerans sp. nov. is proposed.

\section{Description of Amycolatopsis salitolerans sp. nov.}

Amycolatopsis salitolerans (sa.li.to'le.rans. L. n. sal, salis salt; L. part. adj. tolerans tolerating; N.L. part. adj. salitolerans salt tolerating).

Cells are aerobic, Gram-positive, oxidase-negative, catalasepositive and non-motile. Substrate mycelium is branched and white-yellow. White aerial mycelium is produced on oatmeal agar and GTY agar. Diffusible pigments are not produced on the media tested. Grows at $25-45^{\circ} \mathrm{C}$ (optimum $\left.37{ }^{\circ} \mathrm{C}\right)$, at $\mathrm{pH}$ 5.0-8.0 (optimum pH 7.0) and with $0-13 \%(w / v) ~ \mathrm{NaCl}$ (optimum $5 \% \mathrm{NaCl}$ ). Tweens 20, 40 and 60 , aesculin and starch are degraded, but casein, cellulose, chitin, Tween 80 and urea are not. Nitrate reduction is positive, but gelatin liquefaction, milk peptonization and coagulation, and $\mathrm{H}_{2} \mathrm{~S}$ and melanin production are negative. D-Galactose, L-rhamnose, maltose, sorbitol and glycerol are utilized as sole carbon sources, but trehalose, inositol, xylitol, erythritol, sodium acetate, raffinose, D-glucose, L-arabinose, cellobiose, Dribose, D-fructose, D-mannose, D-xylose, lactose, dulcitol, mannitol, trisodium citrate and sodium propionate are not. L-Threonine, L-serine, L-proline, alanine, hypoxanthine, Ltyrosine, adenine and L-asparagine are utilized as nitrogen sources, whereas L-lysine, L-phenylalanine, L-arginine and xanthine are not. With API ZYM, alkaline phosphatase, esterase (C4), esterase lipase (C8), lipase (C14), leucine arylfamidase, valine arylamidase, naphthol-AS-BI-phosphohydrolase, $\alpha$-chymotrypsin, arylamidase, cystine and $N$-acetyl- $\beta$-glucosaminidase are positive, but $\alpha$ - and $\beta$ galactosidase, acid phosphatase, $\beta$-glucuronidase, trypsin, $\alpha$ mannosidase, $\alpha$ - and $\beta$-glucosidase, and $\alpha$-fucosidase are negative. Susceptible to ( $\mu \mathrm{g}$ per disc) novobiocin (5), tetracycline (30), tobramycin (10), clindamycin (15) and erythromycin (15), but resistant to netilmicin (10), penicillin (10), norfloxacin (10), ampicillin (10) and amikacin (30).
The cell wall contains meso-diaminopimelic acid. Mycolic acids are absent. Ribose, glucose and galactose are the major whole-cell sugars. The predominant menaquinone is MK$8\left(\mathrm{H}_{4}\right)$ and the minor menaquinones are MK- $8\left(\mathrm{H}_{6}\right)$, MK$9\left(\mathrm{H}_{4}\right)$ and MK-8 $\left(\mathrm{H}_{2}\right)$. The phospholipid pattern mainly consists of diphosphatidylglycerol, phosphatidylethanolamine, phosphatidylmethylethanolamine and glucosaminecontaining phospholipids. The major fatty acids $(>10 \%)$ are iso- $\mathrm{C}_{16: 0}$ and $\mathrm{C}_{16: 0}$.

The type strain is TRM F $103^{\mathrm{T}}\left(=\mathrm{JCM} 15899^{\mathrm{T}}=\mathrm{CCTCC} \mathrm{AB}\right.$ $208326^{\mathrm{T}}$ ), isolated from a hypersaline habitat of the Tarim basin, north-west China. The DNA G $+\mathrm{C}$ content of the type strain is $66.4 \mathrm{~mol} \%$.

\section{Acknowledgements}

This research was supported by National Natural Science Foundation of China (grant no. 31060003, 31060001), Key Project for Department of Science and Technology of Ministry of Education of China (grant no. 209145), 973 Program (grant no. 2010CB134505), Opening Project by State Key Laboratory of Microbial Resources, Institute of Microbiology, Chinese Academy of Sciences (grant no. SKLMR20090603) and the Opening Project of Key Laboratory of Biogeography and Bioresource in Arid Land, Xinjiang Institute of Ecology and Geography (grant no. LBB-2010-004).

\section{References}

Bian, J., Li, Y., Wang, J., Song, F.-H., Liu, M., Dai, H.-O., Ren, B., Gao, H., $\mathrm{Hu}, \mathbf{X}$. \& other authors (2009). Amycolatopsis marina sp. nov., an actinomycete isolated from an ocean sediment. Int J Syst Evol Microbiol 59, 477-481.

Chun, J., Lee, J.-H., Jung, Y., Kim, M., Kim, S., Kim, B. K. \& Lim, Y.-W. (2007). EzTaxon: a web-based tool for the identification of prokaryotes based on 16S ribosomal RNA gene sequences. Int J Syst Evol Microbiol 57, 2259-2261.

Collins, M. D., Pirouz, T., Goodfellow, M. \& Minnikin, D. E. (1977). Distribution of menaquinones in actinomycetes and corynebacteria. J Gen Microbiol 100, 221-230.

Cui, X.-L., Mao, P.-H., Zeng, M., Li, W.-J., Zhang, L.-P., Xu, L.-H. \& Jiang, C.-L. (2001). Streptimonospora salina gen. nov., sp. nov., a new member of the family Nocardiopsaceae. Int J Syst Evol Microbiol 51, 357-363.

Felsenstein, J. (1985). Confidence limits on phylogenies: an approach using the bootstrap. Evolution 39, 783-789.

Fitch, W. M. (1971). Toward defining the course of evolution: minimum change for a specific tree topology. Syst Zool 20, 406-416.

Gerhardt, P., Murray, R. G. E., Wood, W. A. \& Krieg, N. R. (editors) (1994). Methods for General and Molecular Bacteriology. Washington, DC: American Society for Microbiology.

Groth, I., Schumann, P., Rainey, F. A., Martin, K., Schuetze, B. \& Augsten, K. (1997). Demetria terragena gen. nov., sp. nov., a new genus of actinomycetes isolated from compost soil. Int J Syst Bacteriol 47, 1129-1133.

Guan, T.-W., Xiao, J., Zhao, K., Luo, X.-X., Zhang, X.-P. \& Zhang, L.-L. (2010). Halomonas xinjiangensis sp. nov., a halotolerant bacterium isolated from a salt lake. Int J Syst Evol Microbiol 60, 349-352.

Hasegawa, T., Takizawa, M. \& Tanida, S. (1983). A rapid analysis for chemical grouping of aerobic actinomycetes. J Gen Appl Microbiol 29, 319-322. 
He, L., Li, W., Huang, Y., Wang, L., Liu, Z., Lanoot, B., Vancanneyt, M. \& Swings, J. (2005). Streptomyces jietaisiensis sp. nov., isolated from soil in northern China. Int J Syst Evol Microbiol 55, 1939-1944.

Huang, Y., Paściak, M., Liu, Z., Xie, Q. \& Gamian, A. (2004). Amycolatopsis palatopharyngis sp. nov., a potentially pathogenic actinomycete isolated from a human clinical source. Int J Syst Evol Microbiol 54, 359-363.

Kelly, K. L. (1964). Inter-Society Color Council - National Bureau of Standards Color Name Charts Illustrated with Centroid Colors. Washington, DC: US Government Printing Office.

Kimura, M. (1980). A simple method for estimating evolutionary rates of base substitutions through comparative studies of nucleotide sequences. J Mol Evol 16, 111-120.

Lechevalier, M. P., Prauser, H., Labeda, D. P. \& Ruan, J.-S. (1986). Two new genera of nocardioform actinomycetes: Amycolata gen. nov. and Amycolatopsis gen. nov. Int J Syst Bacteriol 36, 29-37.

Mesbah, M., Premachandran, U. \& Whitman, W. B. (1989). Precise measurement. of the $\mathrm{G}+\mathrm{C}$ content of deoxyribonucleic acid by highperformance liquid chromatography. Int J Syst Bacteriol 39, 159-167.

Minnikin, D. E., Hutchinson, I. G., Caldicott, A. B. \& Goodfellow, M. (1980). Thin-layer chromatography of methanolysates of mycolic acid-containing bacteria. J Chromatogr A 188, 221-233.

Minnikin, D. E., O’Donnell, A. G., Goodfellow, M., Alderson, G., Athalye, M., Schaal, A. \& Parlett, J. H. (1984). An integrated procedure for the extraction of bacterial isoprenoid quinones and polar lipids. J Microbiol Methods 2, 233-241.

Saitou, N. \& Nei, M. (1987). The neighbor-joining method: a new method for reconstructing phylogenetic trees. Mol Biol Evol 4, 406-425.
Sasser, M. (1990). Identification of bacteria by gas chromatography of cellular fatty acids, MIDI Technical Note 101. Newark, DE: MIDI Inc.

Shirling, E. B. \& Gottlieb, D. (1966). Methods for characterization of Streptomyces species. Int J Syst Bacteriol 16, 313-340.

Smibert, R. M. \& Krieg, N. R. (1994). Phenotypic characterization. In Methods for General and Molecular Bacteriology, pp. 607-654. Edited by P. Gerhardt, R. G. E. Murray, W. A. Wood \& N. R. Krieg. Washington, DC: American Society for Microbiology.

Stackebrandt, E., Rainey, F. A. \& Ward-Rainey, N. L. (1997). Proposal for a new hierarchic classification system, Actinobacteria classis nov. Int J Syst Bacteriol 47, 479-491.

Staneck, J. L. \& Roberts, G. D. (1974). Simplified approach to identification of aerobic actinomycetes by thin-layer chromatography. Appl Microbiol 28, 226-231.

Tamura, K., Dudley, J., Nei, M. \& Kumar, S. (2007). MEGA4: Molecular Evolutionary Genetics Analysis (MEGA) software version 4.0. Mol Biol Evol 24, 1596-1599.

Tang, S.-K., Wang, Y., Guan, T.-W., Lee, J.-C., Kim, C.-J. \& Li, W.-J. (2010). Amycolatopsis halophila sp. nov., a halophilic actinomycete isolated from a salt lake. Int J Syst Evol Microbiol 60, 1073-1078.

Wayne, L. G., Brenner, D. J., Colwell, R. R., Grimont, P. A. D., Kandler, O., Krichevsky, M. I., Moore, L. H., Moore, W. E. C., Murray, R. G. E. \& other authors (1987). International Committee on Systematic Bacteriology. Report of the ad hoc committee on reconciliation of approaches to bacterial systematics. Int J Syst Bacteriol 37, 463464.

Williams, S. T. (1967). Sensitivity of streptomycetes to antibiotics as a taxonomic character. J Gen Microbiol 46, 151-160. 